\title{
Неоад"ювантна терапія з наступною лапароскопічною D2-гастректомією при лікуванні місцево-поширеного резектабельного раку шлунка Т3-4
}

\author{
Національний інститут раку, Київ \\ Одержано: 6.04.2021 \\ Прийнято друку: 14.05.2021 \\ DOI: $10.32471 /$ clinicaloncology.2663-466X.41-1.27804
}

\begin{abstract}
Вступ. Прогноз у пацієнтів з місцево-поширеним раком шлунка залишається несприятливим, що підкреслює потребу в покращенні стратегій лікування. Ми проаналізували дані пацієнтів з резектабельним поширеним раком шлунка, які отримували неоад'ювантну хіміотерапію (HАXT) з наступною лапароскопічною субтотальною резекцією шлунка (ЛСРШ) або гастректомією (ЛГЕ) з D2-лімфодисекцією з метою оцінки ефективності та безпеки поєднання даних методів лікування. Методи. У дослідження були включені пацієнти з місцево-поширеною аденокарциномою шлунка (ст3-4 та/або N+ М0), які отримували неоад'ювантну терапію за схемою XELOX (три передопераційні і три післяопераційні 2-тижневі цикли) у Національному інституті раку в період 2016-2018 рр. Перед початком лікування уточнення стадії проводили шляхом лапароскопічного стадіювання. ЛСРШ або ЛГЕ проводили через 3-4 тиж після завершення останнього циклу передопераційної хіміотерапії. Обсяг хірургічного втручання визначали відповідно до локалізації та типу росту пухлини. Результати. У дослідженні було проаналізовано дані 46 хворих. 40 пацієнтів $(86,9 \%)$ отримали три курси терапії XELOX, у той час як 6 пацієнтів $(13,1 \%)$ - два курси лікування. Ступінь відповіді пухлини на проведену хіміотерапію оцінювали відповідно до критеріїв RECIST v1.1. Повний клініко-рентгенологічний регрес пухлини після НАХТ було відмічено в 7(15,2\%) хворих, частковий регрес - у 29 (63,0\%), стабілізацію захворювання - у 6 (13,0\%), у 4 пацієнтів (8,2\%) - прогресію на фоні лікування. Спектр побічних реакцій НАХТ ступеня 3/4 включав: лейкопенію $(21,7 \%)$, нейтропенію $(32,6 \%)$, анемію $(17,4 \%)$, втрату маси тіла $(19,6 \%)$ та нудоту $(21,7 \%)$. Оцінка онкологічного ефекту подальшого хірургічного втручання включала рівень R0-резекції, що становив 97,8\%, та середню кількість видалених регіонарних лімфатичних вузлів - 18,5. Морфологічний повний регрес становив 13,0\%. Післяопераційні ускладнення відмічали у 7 (15,2\%) пацієнтів, із них ступеня 3 (за класифікацією Clavien - Dindo) - у 2 пацієнтів. Усі випадки ускладнень були успішно проліковані консервативно без потреби в повторних операціях. Не було відмічено випадків летальності, пов'язаної з лікуванням. Віддалені результати були наступними: загальна 3-річна виживаність 30,1\%, безрецидивна 3-річна виживаність - 28,5\%. Висновки. Результати проведеного дослідження свідчать, про ефективність та безпеку НАХТ з подальшою ЛСРШ або ЛГЕ із D2-лімфодисекцією при місцево-поширеному РШ. Післяопераційні ускладнення при комбінації НАХT із ЛСРШ або ЛГЕ становили незначний відсоток та не потребували додаткових хірургічних маніпуляцій.
\end{abstract}

Ключові слова: неоад'ювантна терапія; рак шлунка; гастректомія.

\section{ВСТУП}

Рак шлунка (РШ) є одним з найбільш поширених онкологічних захворювань в загальній структурі злоякісних утворень у світі [1], незважаючи на те, що протягом останніх 20 років загальна частота розвитку РШ в певних країнах значно знижується. В Україні захворюваність на РШ залишається майже на незмінно високому рівні, щороку реєструють близько 7,5 тис. нових випадків, переважно на пізніх стадіях (первинні хворі III-IV стадії у 2018 р. - 68,8\%), 55,5\% хворих померли протягом 1-го року після встановлення діагнозу. Хірургічне лікування як самостійний метод не дозволяє досягти 5-річної виживаності, особливо на пізніх стадіях РШ. Два основних клінічних дослідження комбінованого лікування із передопераційною хіміотерапією: MAGIC [2] і FNCLCC/FFCD 9703 [3], показали достовірне покращення загальної виживаності (3В) у порівнянні з лише хірургічним втручанням.

Безпосередня мета неоад’ювантної хіміотерапії (НАХТ) зниження стадії пухлини, підвищення радикальності (R0) хірургічного втручання, основна мета - збільшення безрецидивної і ЗВ пацієнтів. На фоні можливостей НАХТ необхідно брати до уваги профіль токсичності цитостатиків та ̈іх комбінацій з подальшим вивченням ризику збільшення кількості післяопераційних ускладнень, продовження терміну та вартості післяопераційного відновлення [4].

Прогноз у пацієнтів з місцево-поширеним РШ залишається несприятливим у всьому світі, що підкреслює потребу в нових терапевтичних стратегіях. У більшості проведених рандомізованих досліджень НАХТ, у тому числі найвідоміших -
MAGIC та CROSS, основну увагу приділяють компоненту хіміотерапії, у той час як вибір обсягу хірургічної резекції, а також лімфодисекції залишається поза межами обговорення [5, 6]. Після проведення НАХТ радикальна операція є важливим фактором, що визначає загальний прогноз. Лапароскопічна субтотальна резекція шлунка (ЛСРШ) або гастректомія (ЛГЕ) з лімфодисекцією в обсязі D2 є прийнятими стандартами лікування РШ на ранніх стадіях. Лапароскопічні втручання при місцево-поширеному РШ є більш складними для виконання з дотриманням основних принципів абластики і R0-резекції. Було проведено кілька рандомізованих контрольованих досліджень і ретроспективних досліджень, у яких порівнювали ЛСРШ з відкритою операцією при місцево-поширеному РШ. Результати дослідження CLASS-01 показали, що лапароскопічна операція не призводила до погіршення результатів 3-річної безрецидивної та 3В [7]. Проте у цьому клінічному дослідженні жоден пацієнт не отримував НАХТ.

Враховуючи високий потенціал НАХТ у покращенні загальної тривалості життя хворих на РШ, а також виражений місцевий ефект з можливістю зменшення доопераційної стадії РШ поєднання методу НАХТ з лапароскопічною радикальною операцію може значно покращити безпосередні й віддалені результати лікування хворих на розповсюджений РШ, а також значно підвищити якість життя хворих після проведеної комбінованої терапії.

Метою проведеного дослідження була оцінка безпосередніх та віддалених результатів комбінованого лікування, що включало HAXT за схемою XELOX та подальшу лапароскопічну радикальну операцію у хворих на місцево-поширений РШ. 


\section{МАТЕРІАЛИ I МЕТОДИ}

Характеристика пацієнтів. Ми проаналізували дані пацієнтів з місцево-поширеним РШ [8], які отримали НАХТ 3 наступною ЛСРШ або ЛГЕ у Національному інституті раку за період з січня 2016 р. до грудня 2018 р.

У всіх пацієнтів діагностовано РШ, що було підтверджено морфологічно шляхом ендоскопічної біопсії. Ступінь місцевого розповсюдження, а також відсутність віддалених метастазів визначали за допомогою комп'ютерної томографії (КТ) з внутрішньовенним контрастуванням. Використовували мультидетекторну спіральну КТ за наступним протоколом дослідження: пацієнти не приймали іжі протягом 12 год перед процедурою КТ. 3 метою розширення порожнини шлунка за 10 хв перед обстеженням пацієнти приймали 500 700 мл води без газу. Простий скан з динамічною контрастною візуалізацією проводили з товщиною зрізу томографа 3 мм, використовуючи йопромід у якості контрастного засобу. Категорію TNM визначали на основі системи класифікації злоякісних пухлин Union for International Cancer Control [8].

Уточнення відсутності канцероматозу проводили шляхом діагностичної лапароскопії з подальшим цитологічним дослідженням промивних вод (500 мл фізіологічного розчину) з черевної порожнини. Усіх пацієнтів повідомляли про побічні ефекти і ускладнення, що можуть супроводжувати лікування, усі хворі підписали відповідні форми інформованої згоди.

Критерії включення:

1) морфологічно підтверджений РШ на основі ендоскопічної біопсії;

2) відсутність попередньої протипухлинної терапії;

3) місцево-поширений РШ Т3-4 N1-3 M0 за класифікацією Американського спільного комітету з питань раку (American Joint Committee on Cancer - AJCC), 8-ме видання, 2017, відповідно до результатів КТ та даних лапароскопічного стадіювання;
4) задовільний загальний стан хворого (0-1) за шкалою Східної кооперативної онкологічної групи (Eastern Cooperative Oncology Group - ECOG), вік 30-70 років, відсутність порушень гемопоетичної функції, відсутність порушень функцій печінки та нирок, відсутність загострення або декомпенсації супутніх хронічних захворювань;

5) письмова інформована згода отримувати НАХТ перед операцією.

НАХТ. Пацієнти отримували три цикли НАХТ перед операцією. Хіміотерапію проводили за схемою XELOX, що включала внутрішньовенне введення препарату оксаліплатину з розрахунку 130 мг/м² в перший день циклу лікування; пероральний прийом капецитабіну в дозі 2000 мг/м² на добу протягом 1-14 днів. Подальша перерва між циклами хіміотерапії становила 7 днів.

Оцінка клінічної ефективності НАХТ. Після трьох циклів НАХТ виконували повторну фіброгастроскопію, КТ з внутрішньовенним контрастуванням для визначення відповіді пухлини на НАХТ шляхом обчислення розмірів пухлини та оцінки динаміки розмірів регіонарних лімфатичних вузлів. Клінічну ефективність визначали відповідно до критеріїв оцінки відповіді при солідних пухлинах (RECIST v1.1) [9]. Критерії відповіді включали повний регрес пухлини (ПР), частковий регрес, стабілізацію захворювання, та прогресування захворювання.

Оцінка токсичності НАХТ. Токсичність НАХТ класифікували за шкалою 0-IV за Загальними термінологічними критеріями побічних реакцій (Common Terminology Criteria for Adverse Events - СТСАЕ), версія 4.0.

Хірургічне втручання та післяопераційне морфологічне дослідження. Хірургічне втручання планували щонайменше через 21 день після завершення третього циклу НАХТ. Вибір обсягу резекції шлунка - ЛСРШ або ЛГЕ - залежав від локалізації та типу росту первинної пухлини, стандартний обсяг лімфатичної дисекції у всіх випадках був D2, що визначали залежно

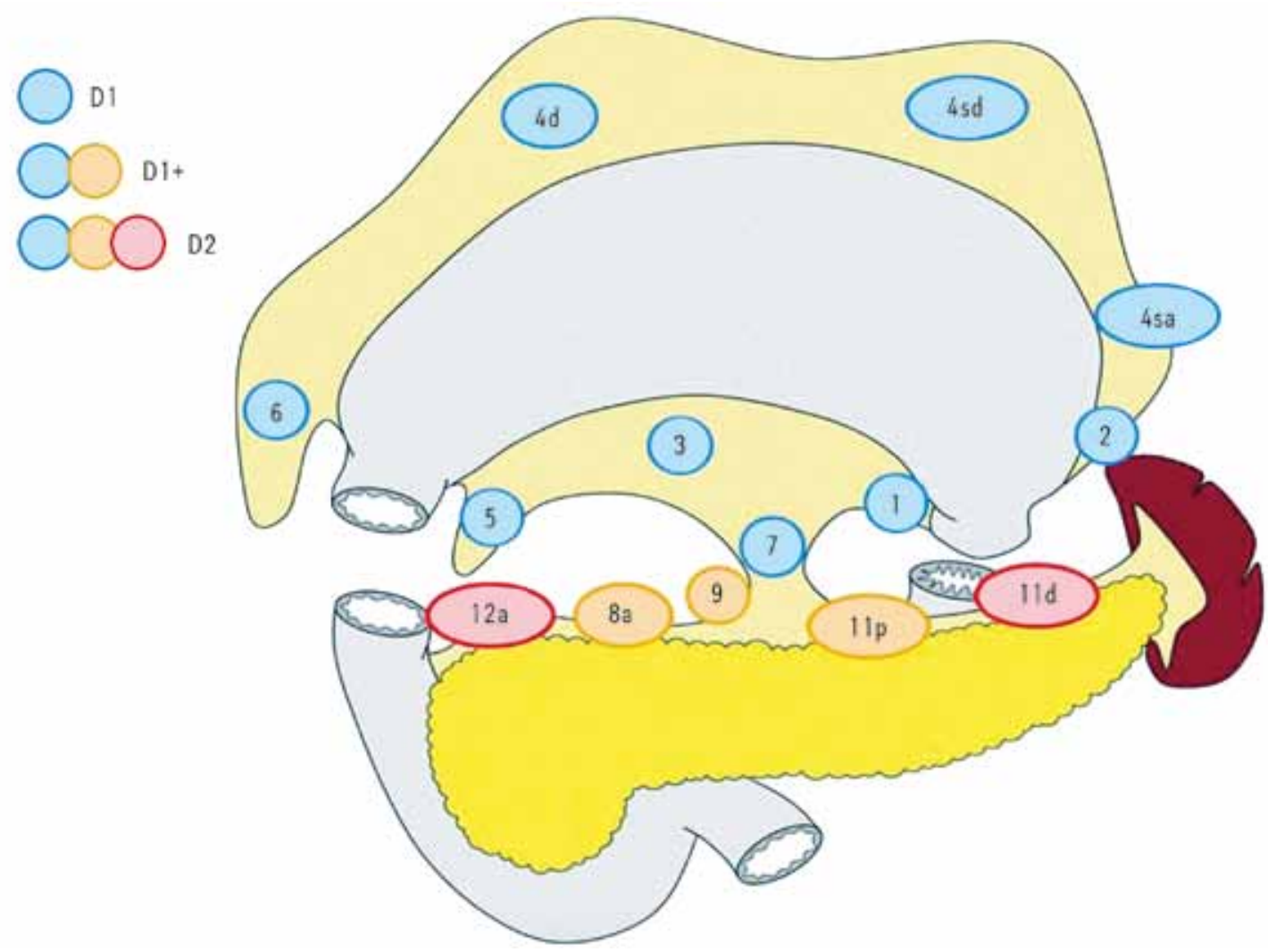

Рис. 1. Вибір обсягу дисекції за JGCA [10] 
від локалізації пухлини шлунка відповідно до рекомендацій Японської асоціації з вивчення раку шлунка (Japanese Gastric Cancer Association - JGCA) (рис. 1) [10].

Операцію проводили за допомогою встановлення 5 троакарів: 2 по 5 мм, 3 по 12 мм (рис. 2). Неперервність шлунковокишкового тракту відновлювали шляхом інтракорпорального гастроентероанастомозу за методом Більрот II при ЛСРШ або езофагоентероанастомозу за методом Ру при ЛГЕ. Екстракцію препарату виконували через умбілікальну зону, шляхом незначного розширення розрізу в місті встановлення оптичного порта в умбілікальній зоні (загальна довжина розрізу не перевищувала 2 см) та використання протективної силіконової рамки. Операції закінчували встановленням 1 дренажу в правий підпечінковий простір. Назогастральні зонди принципово не використовували ні під час, ні після операції.

Після видалення препарату макроскопічну оцінку та подальшу діагностику заморожених зрізів проксимальних та дистальних країв резекції проводили рутинно для всіх пацієнтів. Патологічну відповідь оцінювали за балами шкали регресії пухлини (Tumor Regression Grade - TRG) за критеріями Becker [11]: TRG1a (відсутня залишкова пухлина), TRG1b ( $<10 \%$ залишкової пухлини на зону пухлини), TRG2 (10-50\% залишкової пухлини на зону пухлини) i TRG3 (>50\% залишкової пухлини на зону пухлини). У пацієнтів, у яких були відсутні всі ознаки раку у хірургічних зразках і отриманих лімфатичних вузлах, визначали морфологічний повний регрес. Радикальну резекцію (R0) визначали як резекцію з мікроскопічно негативними краями резекції, без ознак пухлини на макроскопічному та мікроскопічному рівнях. Наявність позитивного краю резекції на мікроскопічному рівні за відсутності таких ознак макроскопічно визначали як резекцію R1.

Оцінка післяопераційних ускладнень. Будь-які ускладнення, що були діагностовані протягом 30 діб після операції, визначали як післяопераційні з подальшою стратифікацією за класифікацією Clavien - Dindo [12].

Статистичні методи. Під час статистичної обробки даних для порівняння категоріальних характеристик використовували критерій хі-квадрат з рівнем значущості $\mathrm{p}<0,05$. Подальший життєвий статус «живий/помер» та дату останнього спостереження було отримано з бази даних Національного канцер-реєстру України станом на кінець 2018 р. Оцінку кривих виживаності проводили з використанням методу Каплана - Мейєра, для порівняння виживаності між групами та за стадіями захворювання використовували лог-ранк критерій з рівнем значущості $\mathrm{p}<0,05$. Для оцінки даних була використана програма R version 2.12.1 (R Project for Statistical Computing, Vienna, Austria; www.r-project. org/)

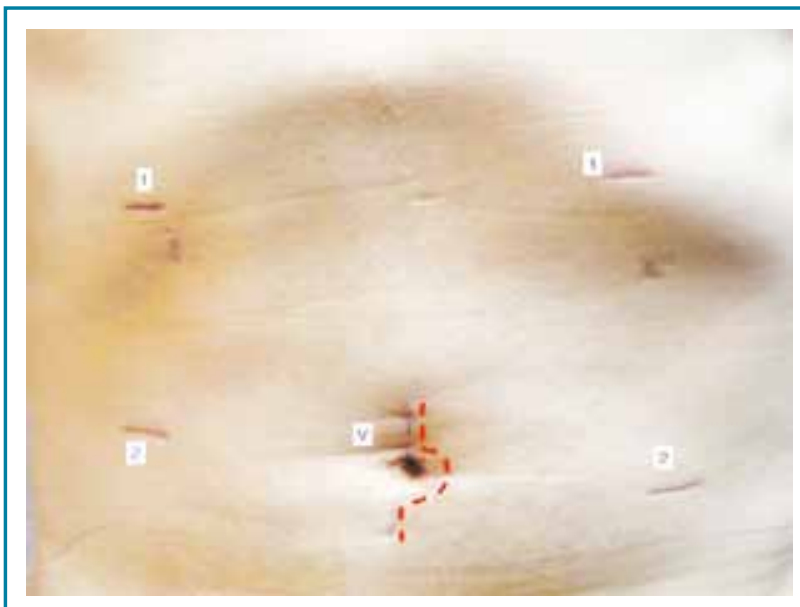

Рис. 2. Фото через 1 міс після ЛГЕ: зони встановлення портів: 1 - порт 5 мм; 2 - порт 12 мм; V - відеопорт, зона екстракції шлунка (2 см)
Для характеристик даних пацієнтів застосовували дескриптивну статистику, використовуючи середнє, стандартне відхилення та відсотки. Усі статистичні дані обробляли за допомогою статистичної програми SPSS, версія 16.0.

\section{РЕЗУЛЬТАТИ}

Характеристика пацієнтів. У дослідження були включені дані 46 хворих на місцево-поширений РШ, шо проходили лікування в Національному інституті раку в період із січня 2016 р. до грудня 2018 р. У табл. 1. наведено характеристики пацієнтів, гістологічні підтипи та передопераційні стадії TNM. Більшість хворих були чоловіками, із задовільним загальним станом здоров'я (більше $80 \%$ мали гарний загальний стан за ECOG 0). Найбільш поширеною морфологічною формою РШ була низькодиференційована (G3) аденокарцинома. У 40 пацієнтів $(86,9 \%)$ передопераційну терапію було проведено в повному обсязі, у той час як 6 пацієнтів $(13,1 \%)$ отримали два курси НАХТ.

Оцінка клінічної ефективності НАХТ. У результаті аналізу результатів НАХT відповідно до критеріїв RECIST v1.1 було встановлено повну клінічну регресію захворювання в 7 хворих $(15,2 \%)$, у $29(63,0 \%)$ пацієнтів - частковий регрес пухлини, що відповідало зменшенню стадії (рис. 3). У 6 (13,0\%) відмічали стабілізацію захворювання і в $4(8,2 \%)$ пацієнтів - прогресію хвороби на фоні хіміотерапії.

Оцінка ускладнень НАХТ. У табл. 2 наведено аналіз профілю токсичності, що спостерігали під час НАХТ. Найбільш поширеними побічними реакціями НАХТ, що сягали ступеня $3 / 4$ були нейтропенія $(30,4 \%)$, лейкопенія $(17,4 \%)$, нудота

Таблиця 1. Демографічні дані пацієнтів $(n=46)$

\begin{tabular}{lc}
\hline & Кількість \\
\hline Вік, медіана (діапазон) & $63(30-70)$ \\
Стать & $36(78,3 \%)$ \\
Чоловіки & $10(21,7 \%)$ \\
Жінки & \\
Гістологічний підтип & $4(8,7 \%)$ \\
Високодиференційована аденокарцинома & $6(13,0 \%)$ \\
Помірно диференційована аденокарцинома & $32(69,6 \%)$ \\
Низькодиференційована аденокарцинома & $4(8,7 \%)$ \\
Перстневидноклітинна карцинома & \\
Клінічна стадія Т & $18(39,1 \%)$ \\
T3 & $28(60,9 \%)$ \\
Т4а & \\
Клінічна стадія N & $20(43,5 \%)$ \\
N1 & $26(56,5 \%)$ \\
N2 & \\
Клінічна стадія ТNM & $24(52,2 \%)$ \\
IIIA & $22(47,8 \%)$ \\
IIIB &
\end{tabular}

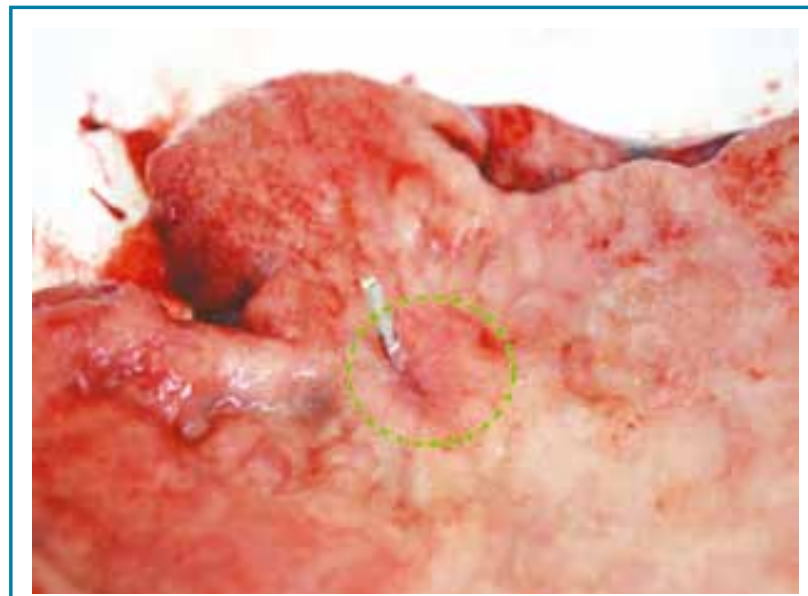

Рис. 3. Макропрепарат: пухлина з клінічним ЧР після НАХТ (зменшення з Т3 до Т1). Потрібним було передопераційне ендоскопічне маркування кліпсою для визначення зони краю резекції 
Таблиця 2. Побічні реакції під час НАХT (n=46)

\begin{tabular}{|c|c|c|c|c|}
\hline Токсичність & Ступінь 1-2 & Ступінь 3 & Ступінь 4 & \% ступеня $3 / 4$ \\
\hline \multicolumn{5}{|l|}{ Гематологічна } \\
\hline Лейкопенія & 12 & 8 & 0 & 17,4 \\
\hline Нейтропенія & 14 & 14 & 0 & 30,4 \\
\hline Тромбоцитопенія & 0 & 0 & 0 & 0 \\
\hline Анемія & 8 & 6 & 0 & 13,0 \\
\hline \multicolumn{5}{|l|}{ Шлунково-кишкова } \\
\hline Нудота & 20 & 6 & 2 & 17,4 \\
\hline Блювання & 10 & 2 & 2 & 8,7 \\
\hline Діарея & 12 & 2 & 0 & 4,3 \\
\hline Закрепи & 8 & 4 & 0 & 8,7 \\
\hline Втрата маси тіла & 6 & 6 & 0 & 13,0 \\
\hline \multicolumn{5}{|l|}{ Лабораторні показники } \\
\hline AcAT & 10 & 0 & 0 & 0 \\
\hline АлАТ & 10 & 0 & 0 & 0 \\
\hline Втомлюваність & 4 & 0 & 0 & 0 \\
\hline Нейросенсорні розлади & 2 & 0 & 0 & 0 \\
\hline
\end{tabular}

АсАТ - аспартатамінотрансфераза; АлАТ - аланінамінотрансфераза.

$(17,4 \%)$, анемія (13\%), втрата маси тіла (13\%) та блювання $(8,7 \%)$. Жодний пацієнт не потребував припинення лікування, всі прояви токсичності мали зворотний характер після відповідного лікування.

Результати хірургічного лікування. Всі 46 пацієнтів отримали хірургічне лікування в обсязі радикальної ЛСРШ або ЛГЕ із лімфатичною дисекцією D2 через 3-4 тиж після останнього циклу НАХТ. У 24 пацієнтів було проведено ЛГЕ, у $22-$ ЛСРШ. У табл. 3 показано результати хірургічного втручання. Рівень резекцій R0 становив $97,8 \%$. Медіана часу операції становила 235 хв, середня інтраопераційна крововтрата -85 мл. Медіана періоду перебування в стаціонарі становила 6,5 доби (діапазон - 4-11).

Післяопераційні ускладнення. Більшість післяопераційних ускладнень були легкого ступеня. Спектр післяопераційних ускладнень, що подовжили госпіталізацію: інфекція післяопераційної рани у 6 пацієнтів, пневмонія - у 2 пацієнтів, післяопераційний панкреатит - в 1 хворого та інтраабдомінальне рідинне скупчення, що потребувало додаткового черезшкірного дренування - у 2 пацієнтів. Не було зафіксовано

Таблиця 3. Характеристики хірургічних втручань (n=46)

\begin{tabular}{lc}
\hline & Кількість \\
\hline Перитонеальна дисемінація пухлини & \\
Негативна & $06(100 \%)$ \\
Позитивна & $0 \%)$ \\
Залишкова пухлина & $45(97,8 \%)$ \\
R0 & $1(2,2 \%)$ \\
R1 & \\
Тип резекції & $24(52,2 \%)$ \\
Тотальна гастректомія & $22(47,8 \%)$ \\
Дистальна субтотальна резекція шлунка & \\
Тип реконструкції & $20(43,5 \%)$ \\
Більрот ІІ & $26(56,5 \%)$ \\
Ру & \\
Час операції (хв) & $235(195-275)$ \\
Медіана (діапазон) & \\
Резектовані лімфовузли & $15(19-38)$ \\
Медіана (діапазон) & \\
Інтраопераційна кровотеча (мл) & $85(40-340)$ \\
Медіана (діапазон) & $2,5(1-5)$ \\
Час до першого відходження газів (діб) & $4,0(3-7)$ \\
Час до першої дефекації (діб) & $5,5(3-7)$ \\
Час до видалення дренажу (діб) & $3,5(2-5)$ \\
Час до рідкої дієти (діб) & $6,5(4-11)$ \\
Післяопераційне перебування в лікарні (діб) & \\
\hline
\end{tabular}

Таблиця 4. Післяопераційні ускладнення

\begin{tabular}{lc}
\hline \multicolumn{1}{c}{ Класифікація Clavien - Dindo } & Кількість \\
\hline Ступінь I & \\
Хірургічна інфекція & $6(13 \%)$ \\
Ступінь II & $4(8,7 \%)$ \\
Пневмонія & $1(2,2 \%)$ \\
Панкреатична фістула & $0(0 \%)$ \\
Ступінь III & $2(4,3 \%)$ \\
Післяопераційна кровотеча & 0 \\
Інтраабдомінальне скупчення рідини & 0 \\
Стеноз анастомозу & \\
Неспроможність анастомозу &
\end{tabular}

смертей внаслідок операції і жодний пацієнт не потребував повторного хірургічного втручання. Післяопераційні ускладнення відповідно до класифікації Clavien - Dindo наведено в табл. 4. Тільки у 2 пацієнтів виявляли ускладнення 3-го ступеня. Один пацієнт з післяопераційним панкреатитом лікувався консервативно і показав найдовший час одужання (21 доба). Такі ускладнення, як пневмонія та інтраабдомінальне рідинне скупчення, продовжували час післяопераційного перебування в лікарні і воно становило 15 та 18 діб відповідно.

Морфологічна оцінка відповіді на НАХТ. Морфологічну оцінку відповіді на НАХТ проводили згідно з критеріями TRG1a у $6(13,0 \%)$ пацієнтів, TRG1b - у $12(26,1 \%)$ хворих, TRG2 - у $16(34,8 \%)$ i TRG3 - у $12(26,1 \%)$ пацієнтів. У нашому дослідженні рівень повної морфологічної відповіді становив 13,0\%. У табл. 5 наведено дані морфологічного дослідження післяопераційного матеріалу.

Післяопераційне лікування. Післяопераційні три цикли ад'ювантної хіміотерапії за схемою XELOX були проведені у 42 із 46 пацієнтів. Чотири пацієнти відмовилися від ад'ювантної хіміотерапії.

Спостереження. Останнє спостереження було проведено у 2019 р., період спостереження коливався в межах 6-24 міс, період медіани спостереження становив 12 міс. Наприкінці періоду спостереження 38 пацієнтів залишалися живими, 6 пацієнтів померли і з 2 пацієнтами було втрачено контакт. Прогресування хвороби у вигляді віддалених метастазів було відмічено у 10 пацієнтів, із яких у 2 виявили метастази в легені, у 6 - в печінку і у 2 - поліорганні метастази.

Показник 3-річної ЗВ становив 30,1\%, 3-річна безрецидивна виживаність дорівнювала 28,5\%, $95 \%$ довірчий інтервал (ДІ). Віддаленні результати лікування за Капланом - Мейєром представлені на рис. 4.

Таблиця 5. Післяопераційне морфологічне дослідження (n=46)

Глибина інвазії пухлини (урТ)

TO

T1

$\mathrm{T} 2$

T2

T4a

Метастази в лімфатичних вузлах (ypN)

NO

$\mathrm{N} 1$

N2

Стадія ур

0 6(13,0\%)

I

II

III

Гістологічна відповідь

TRG1a

TRG1b

TRG2

TRG3
Кількість

$6(13,0 \%)$

$6(13,0 \%)$

$14(30,4 \%)$

$18(39,1 \%)$

$2(4,3 \%)$

$24(52,2 \%)$

$14(30,4 \%)$

$8(17,4 \%)$

$6(13,0 \%)$
$14(30,4 \%)$

$20(43,5 \%)$

$6(13,0 \%)$

$6(13,0 \%)$

$12(26,1 \%)$

$16(34,8 \%)$

$12(26,1 \%)$ 


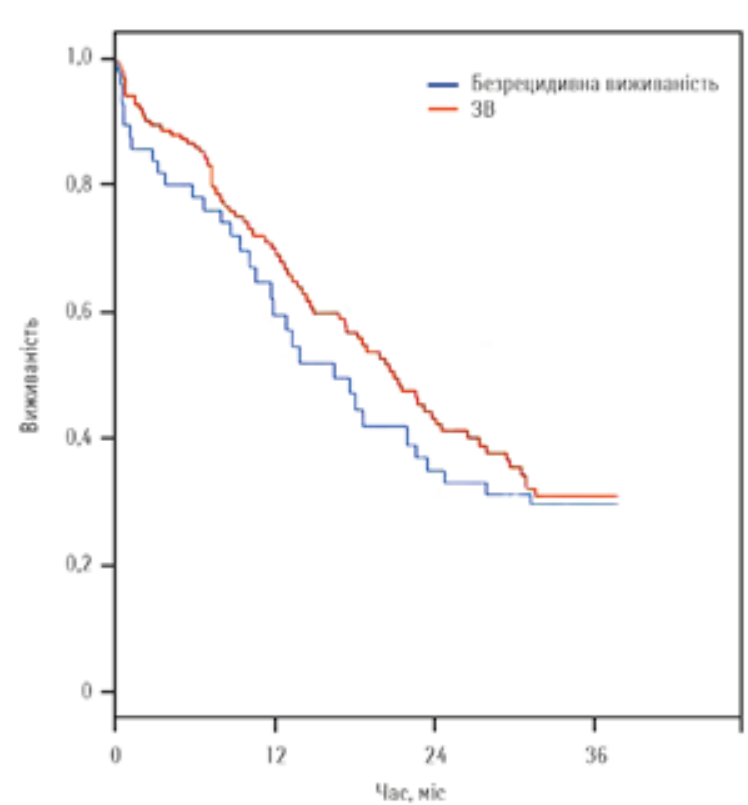

Рис. 4. Віддаленні результати лікування за Капланом Мейєром

\section{ОБГОВОРЕННЯ}

Незважаючи на певні успіхи сучасних методів лікування, РШ посідає третю сходинку в загальній структурі смертності від онкологічних захворювань у всьому світі. Враховуючи епідеміологічні географічні особливості РШ, у Китаї реєструють найбільшу кількість нових випадків, що становить більше 40\% всіх первинних щорічних випадків РШ [1]. У зв'язку з відсутністю специфічних симптомів на ранніх стадіях поширений РШ відмічають у більше $80 \%$ всіх первинних пацієнтів з РШ в Україні [13].

З розвитком медичних технологій та накопиченням досвіду хірурги можуть оцінювати передопераційну стадію пухлини більш точно за допомогою ендосонографії, КТ, магнітнорезонансної томографії, позитронно-емісійної комп’ютерної томографії, діагностичної лапароскопії з флуоресцентними барвниками та ін. [14-16]. Незважаючи на прогрес у методах виконання хірургічної резекції, лімфодисекції, післяопераційної реконструкції тощо, у більшості пацієнтів з пізніми стадіями РШ, у яких хірургічну операцію використовували як самостійний метод лікування, відмічають високий ризик раннього виникнення метастазів. На сьогодні не існує міжнародного консенсусу щодо оптимального вибору НАХT для поєднання з операцією у пацієнтів з резектабельним РШ як методу досягти зниження стадії пухлини, покращення радикальності операції та ерадикації мікрометастазів, особливо у пацієнтів з місцево-поширеними пухлинами шлунка [17].

Два перші клінічні дослідження передопераційної хіміотерапії показали значуще підвищення виживаності без ознак хвороби та ЗВ при пізніх стадіях РШ та гастроезофагеального раку. Дослідження MAGIC продемонструвало покращення ЗВ внаслідок комбінування хірургічного втручання з НАХТ на пізніх стадіях РШ [2]. Результати даного дослідження свідчать, що НАХТ в режимі ЕСF (епірубіцин, цисплатин та інфузії 5-фторурацилу) призводила до зменшення розмірів пухлини та достовірно подовжувала 5-річну 3В від 23\% в групі лише хірургічного втручання до $36 \%$ в групі НАХТ. У подальшому результати дослідження МАGIC стали підставою для консенсусного рішення Європейської асоціації онкологів (European Society for Medical Oncology - ESMO) щодо оптимального обсягу хірургічного втручання при місцево-розповсюдженому РШ, обов’язково з лімфатичною дисекцією, не меншою ніж D2, та призначенням передопераційної хіміотерапії $[18,19]$.
У Франції було проведено багатоцентрове дослідження III фази ACCORD07/FFCD, присвячене HAXT при РШ. Передопераційна хіміотерапія включала інфузії 5-фторурацилу та цисплатину. У результаті було продемонстровано значуще підвищення показників безрецидивної та ЗВ в групі комбінованого лікування [3].

Комбіновані режими хіміотерапії, як правило, асоційовані зі значно вищими рівнями об'єктивної відповіді і кращою виживаністю у порівнянні з монотерапією. На даний час відсутнє консенсусне рішення щодо застосування комбінації трьох або двох цитостатиків при НАХТ у пацієнтів з місцево-поширеним РШ [5, 14-22].

У клініці Національного інституту раку, починаючи з 2016 р., широке застосування в якості НАХТ при РШ набула схема XELOX. На даний момент існує мало досліджень ефективності та побічних реакцій комбінації XELOX при РШ, особливо при застосуванні в якості НАХТ, зокрема рівня післяопераційних ускладнень та показників післяопераційної летальності. У проведеному нами дослідженні в пацієнтів, які отримували HAXT за схемою XELOX, була зареєстрована добра переносимість та допустима кількість побічних ефектів. За винятком 6 хворих, усі інші пацієнти завершили повністю заплановані три цикли НАХТ. Найбільш частими побічними реакціями були нейтропенія, лейкопенія і шлунково-кишкова токсичність. Відповідно до отриманих даних, ступінь $3 / 4$ лейкопенії, нейтропенії та анемії відмічали у 17,4; 30,4; і 13\% пацієнтів відповідно. Усі прояви гематологічної токсичності НАХТ швидко коригували відповідними препаратами та вони не призвели до значного відтермінування подальшого лікування.

Можливий вплив НАХТ на післяопераційні ускладнення і смертність $€$ іншою критичною проблемою, що може обмежити рекомендації щодо комбінованого підходу [22, 23]. У попередніх роботах найбільш частими були такі післяопераційні ускладнення, як інфекції хірургічного поля, включаючи інфекції рани та інтраабдомінальні абсцеси, а також неспроможність анастомозу [23, 24]. У нашому дослідженні ускладнення після операції відмічали у 7 пацієнтів (15,2\%), проте більшість можна віднести до незначних. Інфекції післяопераційної рани $(13,0 \%)$ були найбільш помітним післяопераційним ускладненням. Післяопераційні ускладнення ступеня 3 за класифікацією Clavien - Dindo виявляли тільки у 2 хворих. Відповідно до отриманих результатів, можна зробити висновок про безпеку протокола у хіміотерапії XELOX як неоад'ювантного режиму, що не збільшує кількість післяопераційних ускладнень. Під час порівняльної оцінки прогностичних факторів було виявлено, що розміри і локалізації пухлини $[25,26]$, морфологічний підтип [26, 27] і радикальність хірургічного втручання (R0) [24, 25, 28, 29] мають основний вплив на прогноз при операбельному (M0) РШ. При місцево-поширеному РШ хірург має докласти всіх зусиль для досягнення радикального R0 видалення всієї пухлини для уникнення можливості позитивного мікроскопічного краю [30]. Окрім цього, при проведенні НАХТ зменшення пухлини дозволяє досягти вищого рівня радикальності операцій, відповідно, в проведеному нами дослідженні рівень R0 резекцій становив 97,8\%. Хоча дослідження включало дані винятково про малоінвазивні хірургічні втручання, його результати були співставними з висновками інших ретроспективних досліджень, у яких застосовували НАХТ за подвійним чи потрійним режимами, що містять оксаліплатин (SOX: оксаліплатин і TS-1; CAPOX: оксаліплатин і капецитабін; FOLFOX7: оксаліплатин, лейковорин і 5-фторурацил). Наше дослідження показало набагато вищі відсотки повної і часткової відповіді у зв'язку з високою терапевтичною ефективністю комбінації XELOX. На терапевтичну ефективність протоколу XELOX також вказує високий рівень морфологічно підтвердженої відповіді на НАХТ та рівень повної патологічної відповіді. Досягнення ПР після НАХТ 
звичайно пов'язане з кращою ЗВ та виживаністю без ознак хвороби [26, 31]. Наші результати показали ПР у $13 \%$ пацієнтів.

Лапароскопічні резекції шлунка на сьогодні, виходячи 3 даних численних досліджень в країнах Азії, можуть бути рекомендовані при лікуванні ранніх стадій РШ [29, 32]. Лише кілька досліджень показали ефективність лапароскопічної резекції у пацієнтів з місцево-поширеним РШ [30, 33].

У багатоцентровому рандомізованому дослідженні III фази KLASS-02 було проведено порівняння хірургічних та онкологічних результатів ЛСРШ з відкритою хірургічною операцією при місцево-поширеному РШ [31, 34]. Автори відмічають достовірно нижчий рівень ранніх післяопераційних ускладнень та скорочення часу перебування у лікарні в групі малоінвазивного лікування. Багатоцентрове проспективне рандомізоване контрольоване дослідження CLASS-01, що було проведено в Китайській Народній Республіці, надало оцінку хірургічної безпеки та віддалених результатів ЛСРШ у порівнянні зі стандартною відкритою хірургічною операцією при пізніх стадіях РШ. Післяопераційне одужання було достовірно швидшим у групі лапароскопічного втручання, навіть при порівняльному аналізі з дослідженням KLASS-02, проведеним у Південній Кореї. Шо більш важливо, рівень післяопераційних ускладнень при ЛСРШ у хворих на місцевопоширений РШ достовірно не відрізнявся порівняно з групою відкритого хірургічного втручання [35]. Показники 3-річної безрецидивної виживаності відповідно становили 76,5\% у групі ЛСРШ і 77,8\% - у групі відкритого хірургічного втручання [7]. Наведені результати свідчать на користь можливих переваг застосування малоінвазивних втручань при лікуванні місцево-поширеного РШ. Проте у дослідженні CLASS-01 жодний пацієнт не отримував НАХТ. Питання про перспективи лапароскопічних хірургічних втручань після НАХТ при пізніх стадіях РШ до сьогодні не мають аргументованих відповідей. На даний момент розпочато 2 рандомізованих дослідження II фази у Китаї та Японії, проте їх результати ще не опубліковані [32, 36-38]. На основі наявних даних ми застосовували ЛГЕ або ЛСРШ із D2-лімфодисекцією при місцево-поширеному РШ в нашій клініці за умови проведення попередньої НАХТ.

Початок хірургічного втручання лапароскопічним шляхом при місцево-поширеному РШ може запобігти експлоративній лапаротомії. Дані досліджень, присвячених діагностичній ефективності методів КТ з внутрішньовенним контрастуванням та позитронно-емісійної комп'ютерної томографії 3 контрастуванням 18F-фтордезоксіглюкозою при РШ, показали їх недостатню чутливість при виявленні перитонеального канцероматозу, що не перевищувала 53 і 68\% відповідно [39, 40]. Відповідно до даних Меморіального онкологічного центру ім. Слоуна-Кеттерінга (Memorial Sloan Kettering Cancer Center), США, аналіз 10-річного досвіду проведення діагностичної лапароскопії перед хірургічним втручанням показав можливість зміни діагнозу в гіршу сторону в $31 \%$ випадків у зв'язку з детекцією віддалених метастазів (M1), що раніше не визначилися при інших методах обстеження [41]. Таким чином, на наш погляд, уточнення стадії РШ шляхом діагностичного лапароскопічного стадіювання є принциповим методом діагностики для уточнення стадії РШ.

Оптимальна методика реконструкції шлунково-кишкового тракту після ЛСРШ відрізняється залежно від клінічного закладу. В Інституті раку при ЛРСШ ми переважно застосовували реконструкцію за Більротом II.

Отримані нами дані післяопераційного морфологічного аналізу свідчать, що у всіх 46 пацієнтів виконання операцій малоінвазивним шляхом забезпечувало адекватний обсяг лімфодисекції - медіана кількості видалених лімфатичних вузлів становила 15. Незначна інтраопераційна крововтрата та швидке післяопераційне одужання також підтверджує безпеку обраного підходу у виконанні ЛСРШ і ЛГЕ. За результатами аналізу післяопераційних ускладнень та онкологічних результатів проведених оперативних втручань було встановлено, що ЛСРШ або ЛГЕ після НАХТ можуть бути настільки ж безпечними та ефективними, як і відкрите хірургічне втручання при розповсюдженому РШ. Проте ці висновки вимагають вищого рівня доказів за результатами багатоцентрових досліджень.

\section{ВИСНОВКИ}

Результати проведеного дослідження свідчать, що НАХТ з подальшою ЛСРШ або ЛГЕ з D2-лімфодисекцією при місцево-поширеному РШ є ефективними та безпечними. Відсоток післяопераційних ускладнень при комбінації НАХТ з ЛСРШ або ЛГЕ був незначним, та вони не потребували додаткових хірургічних маніпуляцій. Ретроспективний характер дослідження може викликати певну систематичну похибку. На наші результати міг вплинути короткий період спостереження пацієнтів. Відсутність групи контрольного лікування і малий розмір вибірки дослідження також можуть знизити достовірність результатів. Ці результати слід надалі підтвердити у майбутніх проспективних рандомізованих контрольованих дослідженнях.

\section{СПИСОК ВИКОРИСТАНОÏ ЛІТЕРАТУРИ}

Bray, F., Ferlay, J., Soerjomataram, I., Siegel, R. L., Torre, L. A., \& Jemal, A. (2018). Global cancer statistics 2018: GLOBOCAN estimates of incidence and mortality worldwide for 36 cancers in 185 countries. Cancer Journal for Clinicians, 68(6), 394-424. doi.org/10.3322/caac.21492.

Cunningham, D., Allum, W. H., Stenning, S.P. Thompson, J. N., Van de Velde, C. J., Nicolson, M., ..., Chua, Y. J. (2006). Perioperative chemotherapy versus surgery alone for resectable gastroesophageal cancer. New England Journal of Medicine, 355(1), 11-20. doi: 10.1056/NEJMoa055531.

Ychou, M., Boige, V., Pignon, J.-P., Conroy, T., Bouché, O., Lebreton, G., ... Rougier, P. (2011). Perioperative chemotherapy compared with surgery alone for resectable gastroesophageal adenocarcinoma: an FNCLCC and FFCD multicenter phase III trial. Journal of Clinical Oncology, 29(13), 1715-1721. doi: 10.1200/JCO.2010.33.0597.

Knight, G., Earle, C. C., Cosby, R., Coburn, N., Youssef, Y., Malthaner, R., \& Wong, R. K. (2013). Neoadjuvant or adjuvant therapy for resectable gastric cancer: a systematic review and practice guideline for North America, Gastric Cancer, 16(1), 28-40. doi: 10.1007/s10120-012-0148-3.

Bray, F., Ferlay, J., Soerjomataram, I., Siegel, R. L., Torre, L. A., \& Jemal, A. (2018). Global cancer statistics 2018: GLOBOCAN estimates of incidence and mortality worldwide for 36 cancers in 185 countries. Cancer Journal for Clinicians, 68(6), 394-424. doi.org/10.3322/caac.21492.

Raigani, S., Hardacre, J. M., Kim, J., \& Ammori, J. B. (2014). Trends in the surgical treatment of gastric adenocarcinoma. Annals of Surgical Oncology, 21(2), 569-574. doi: 10.1245/s10434-013-3314-X.

Yu, J., Huang, C., Sun, Y., Su, X., Cao, H., Hu, J., ..., Li, G. (2019). Effect of laparoscopic vs open distal gastrectomy on 3-year disease-free survival in patients with locally advanced gastric cancer, JAMA, 321(20), 1983-1992. doi: 10.1001/jama.2019.5359.

Amin, M. B., Edge, S. B., Greene, F. L. (2017). AJCC Cancer Staging Manual ( $8^{\text {th }}$ ed.). Springer: New York.

Eisenhauer, E. A., Therasse,P., Bogaerts, J., Schwartz, L. H., Sargent, D., Ford, R., ... Verweij, J. (2009). New response evaluation criteria in solid tumours: revised RECIST guideline (version 1.1). European Journal of Cancer, 45(2), 228-247, doi: 10.1016/j.ejca.2008.10.026.

Japanese Gastric Cancer Association (2017). Japanese gastric cancer treatment guidelines 2014 (ver. 4). Gastric Cancer, 20(1), 1-19. doi: 10.1007/s10120-016-0622-4. Becker, K., Mueller, J. D., Schulmacher, C. Ott, K., Fink, U., Busch, R., ... Höfler, H. (2003). Histomorphology and grading of regression in gastric carcinoma treated with neoadjuvant chemotherapy. Cancer, 98(7). 1521-1530. doi: 10.1002/cncr.11660.

Dindo, D., Demartines, N., \& Clavien, P.-A. (2004). Classification of surgical complications. Annals of Surgery, 240(2), 205-213. doi: 10.1097/01.sla.0000133083.54934.ae.

Федоренко, З. П., Гулак, Л. О., Михайлович, Ю. Й., Горох, Є. Л., Рижов, А. Ю., Сумкіна, О. В., \& Куценко, Л. Б. (2020). Рак в Україні, 2018-2019. Захворюваність, смертність, показники діяльності онкологічної служби/гол. ред. О.О. Колеснік. Бюлетень Національного канцер-реєстру України, 21,101.

Fusaroli, P., Kypreos, D., Alma, C., Petrini, A., \& Caletti, G. (2011). Scientific publications in endoscopic ultrasonography: changing trends in the third millennium. Journal of Clinical Gastroenterology, 45(5), 400-404. doi: 10.1097/MCG.0b013e3181fbde42.

Mocellin, S., \& Pasquali, S. (2015). Diagnostic accuracy of endoscopic ultrasonography (EUS) for the preoperative locoregional staging of primary gastric cancer. Cochrane Database of Systematic Reviews, 2, CD009944 doi: gastric cancer. Cochrane Database

Fusaroli, P., Serrani, M., Lisotti, A., D’Ercole, M., Ceroni L., \& Caletti, G. (2015). Performance of the forward-view echoendoscope for pancreaticobiliary examination in patients with status post-upper gastrointestinal surgery. Endoscopic Ultrasound, 4(4), 336-341. doi: 10.4103/2303-9027.170427.

Zaanan, A., Bouché, O., Benhaim, L., Buecher, B., Chapelle, N., Dubreuil, O.... Michel, P. (2018). Gastric cancer: French intergroup clinical practice guidelines for diagnosis, treatments and follow-up (SNFGE, FFCD, GERCOR, UNICANCER, SFCD, SFED, SFRO). Digestive and Liver Disease, 50(8), 768-779. doi: 10.1016/j.dld.2018.04.025

Rausei, S., Boni, L., Rovera, F., \& Dionigi, G. (2013). Locally advanced gastric cancer: a new definition to standardise. Journal of Clinical Pathology, 66(2), 164-165. doi: 10.1136/jclinpath-2012-201176.

Smyth, E. C., Verheij, M., Allum, W., Cunningham, D., Cervantes, A., \& Arnold, D. (2016). Gastric cancer: ESMO clinical practice guidelines for diagnosis, treatment and follow-up. Annals of Oncology, 27(5), v38-49. doi: 10.1093/annonc/mdw350. 
Mohammad, N. H., ter Veer, E., Ngai, L., Mali, R., van Oijen, M. G., \& van Laarhoven, H. W. (2015). Optimal first-line chemotherapeutic treatment in patients with locally advanced or metastatic esophagogastric carcinoma: triplet versus double chemotherapy: a systematic literature review and meta-analysis. Cancer and Metastasis Reviews, 34(3), 429-441. doi: 10.1007/s10555-015-9576-y.

Smyth, E. C., Verheij, M., Allum, W., Cunningham, D., Cervantes, A., \& Arnold D. (2016). Gastric cancer: ESMO Clinical Practice Guidelines for diagnosis, treatment and follow-up. Annals of Oncology, 27(5), v38- v49. doi: 10.1093/annonc/mdw350.

Yoon, S., Yoo, C., Ryu, M.-H. Kang, M. J., Ryoo, B. Y., Park, S. R., \& Kang, Y. K.

(2017). Phase 2 study of adjuvant chemotherapy with docetaxel, capecitabine, and cisplatin in patients with curatively resected stage IIIB-IV gastric cancer. Gastric Cancer, 20(1), 182-189. doi: 10.1007/s10120-015-0580-2.

Claassen, Y. H. M., Hartgrink, H. H., Dikken, J. L., de Steur, W. O., van Sandick, J. W., van Grieken, N. C. T., ..., van de Velde, C. J. H. (2018). Surgical morbidity and mortality after neoadjuvant chemotherapy in the CRITICS gastric cancer trial. European Journal of Surgical Oncology, 44(5), 613-619. doi: 10.1016/j.ejso.2018.02.004.

Treoule, P., Trojan, J., Bechstei, W., \& Woeste, G. (2015). Impact of neoadjuvan chemotherapy on postoperative morbidity after gastrectomy for gastric cancer. Digestive Surgery, 32(4), 229-237. doi: 10.1159/000381884.

Pacelli, F., Papa, V., Caprino, P., Sgadari, A., Bossola, M., \& Doglietto, G. B. (2001). Proximal compared with distal gastric cancer: multivariate analysis of prognostic factors. American Journal of Surgery, 67(7), 697-703.

$\mathrm{Zu}, \mathrm{H}$., Wang, F., Ma, Y., \& Xue, Y. (2013). Stage-stratified analysis of prognostic significance of tumor size in patients with gastric cancer. PLoS One, 8(1), e54502. doi: 10.1371/journal.pone.0054502.

Lee, H. H., Song, K. Y., Park, C. H., \& Jeon, H. M. (2012). Undifferentiated-type gastric adenocarcinoma: prognostic impact of three histological types. World Journal of Surgical Oncology, 10(1), 254. doi: 10.1186/1477-7819-10-254.

Liang, Y., Ding, X., Wang, X., Wang, B., Deng, J., Zhang, L., \& Liang, H. (2015). Prognostic value of surgical margin status in gastric cancer patients. ANZ Journal of Surgery, 85(9), 678-684. doi: 10.1111/ans.12515.

Aurello, P., Magistri, P., Nigri, G. Petrucciani, N., Novi, L., Antolino, L., . Ramacciato, G. (2014). Surgical management of microscopic positive resection margin after gastrectomy for gastric cancer: a systematic review of gastric R1 management. Anticancer Research, 34(11), 6283-6288.

Catena, F., Di Battista, M., Ansaloni, L., Pantaleo, M., Fusaroli, P., Di Scioscio, V.,

Pinna, A. (2012). Microscopic margins of resection influence primary gastrointestina stromal tumor survival. Oncology Research and Treatment, 35(11), 645-648. doi: $10.1159 / 000343585$

Li, Z., Shan, F., Wang, Y., Zhang, L., Li, S., Jia, Y., ..., Ji, J. (2018). Correlation of pathological complete response with survival after neoadjuvant chemotherapy in gastric or gastroesophageal junction cancer treated with radical surgery: a metaanalysis. PLoS One, 13(1), e0189294. doi: 10.1371/journal.pone.0189294.

Lianos, G. D., Rausei, S., Ruspi, L., Galli, F., Mangano, A., Roukos, D.H., ..., Boni, L. (2014). Laparoscopic gastrectomy for gastric cancer: current evidences. International Journal of Surgery, 12(12), 1369-1373. doi: 10.1016/j.ijsu.2014.10.014.

Quan, Y., Huang, A., Ye Xu, M., Zhuang, B., Zhang, P., Yu, B., \& Min, Z. (2016). Comparison of laparoscopic versus open gastrectomy for advanced gastric cancer: an updated meta-analysis. Gastric Cancer, 19(3), 939-950. doi: 10.1007/s10120-015-0516-x.

Lee, H. J., Hyung, W. J., Yang, H. K., Han, S. U., Park,Y. K., An, J. Y., ... Kim, M. C. (2019). Short-term outcomes of a multicenter randomized controlled trial comparing laparoscopic distal gastrectomy with D2 lymphadenectomy to open distal gastrectomy for locally advanced gastric cancer (KLASS-02-RCT). Annals of Surgery, 270(6), 983-991. doi: 10.1097/SLA.0000000000003217.

Hu, Y., Huang, C., Sun, Y., Su, X., Cao, H., Hu, J., ... Li, G. (2016). Morbidity and mortality of laparoscopic versus open $\mathrm{D} 2$ distal gastrectomy for advanced gastric cancer: a randomized controlled trial. Journal of Clinical Oncology, 34(12), 1350-1357. doi: 10.1200/JCO.2015.63.7215.

Li, Z., Shan,F., Ying X., Ren, H., Li, S., Jia, Y., ... Ji, J. (2018). Laparoscopic or open distal gastrectomy after neoadjuvant chemotherapy for advanced gastric cancer: study protocol for a randomised phase II trial. BMJ Open, 8(8), e021633. doi 10.1136/bmjopen-2018-021633

Yoshikawa, T., Fukunaga, T, Taguri, M., Kunisaki, C, Sakuramoto, S, Ito, S, ... Tsuburaya, A. (2012). Laparoscopic or open distal gastrectomy after neoadjuvant chemotherapy for operable gastric cancer, a randomized Phase II trial (LANDSCOPE trial). Japanese Journal of Clinical Oncology, 42(7), 654-657. doi: 10.1093/jico/hys057.

Li, Z., Shan, F., Wang, Y., Jia, Y., Zhang, L., Yin, D., \& Ji, J. (2012). Laparoscopic versus open distal gastrectomy for locally advanced gastric cancer after neoadjuvan chemotherapy: safety and short-term oncologic results. Surgical Endoscopy, 30(10), 4265-4271. doi: 10.1007/s00464-015-4739-z.

Dassen, AE, Lips, DJ, Hoekstra,CJ, Pruijt JF, Bosscha K. (2009). FDG-PET has no definite role in preoperative imaging in gastric cancer. European Journal of Surgical Oncology, 35, 449-455. doi: 10.1016/j.ejso.2008.11.010.

Lim, J. S., Yun, M. J., Kim, M.-J., Hyung, W. J., Park, M. S., Choi, J. Y., ... Kim, K. W. (2006). CT and PET in stomach cancer: preoperative staging and monitoring of response to therapy. Radiographics, 26, 143-156. doi: 10.1148/rg.261055078.

Sarela, A.I., Lefkowitz, R., Brennan, M.F., \& Karpeh, M.S. (2006). Selection of patients with gastric adenocarcinoma for laparoscopic staging. American Journal of Surgery, 191, 134-138. doi: 10.1016/j.amjsurg.2005.10.015.

\section{Неоадъювантная терапия с последующей лапароскопической D2-гастрэктомией при лечении местно-распространенного резектабельного рака желудка Т3-4 \\ А.В. Лукашенко, А.В. Бойко}

Национальный институт рака, Киев

Резюме. Введение. Прогноз у пациентов с местнораспространенным раком желудка остается неблагоприятным, что подчеркивает потребность в улучшении стратегий лечения. Мы проанализировали данные пациентов с резектабельным распространенным раком желудка, которые получили неоадъювантную химиотерапию (НАХТ) с последующей лапароскопической субтотальной резекцией желудка (ЛСРЖ) или гастрэктомию (ЛГЕ) с D2-лимфодиссекцией для оценки эффективности и безопасности сочетания данных методов лечения. Методы. В исследование были включены пациенты с местно-распространенной аденокарциномой желудка (сT3-4 и / или N + M0), которые получили неоадъювантную терапию по схеме XELOX (три предоперационные и три послеоперационные 2-недельные циклы) в Национальном институте рака с 2016 по 2018 гг. Перед началом лечения уточнение стадии проводили путем лапароскопического стадирования. ЛСРЖ или ЛГЕ проводили через 3-4 нед после завершения последнего цикла предоперационной химиотерапии. Объем хирургического вмешательства определяли согласно локализации и типа роста опухоли. Результаты. В исследовании были проанализированы данные 46 пациентов. 40 пациентов $(86,9 \%)$ получили три курса терапии XELOX, в то время как 6 пациентов $(13,1 \%)$ получили два курса лечения. Степень ответа опухоли на проводимую химиотерапию оценивали в соответствии с критериями RECIST v1.1. Полный клинико-рентгенологический регресс опухоли после НАХТ был отмечен у $7(15,2 \%)$ больных, частичный регресс - у $29(63,0 \%)$, стабилизацию заболевания - у $6(13,0 \%)$, у 4 пациентов $(8,2 \%)$ - прогрессия на фоне лечения. Спектр побочных реакций НАХТ степени $3 / 4$ включал: лейкопению $(21,7 \%)$, нейтропению $(32,6 \%)$, анемию $(17,4 \%)$, уменьшение массы тела $(19,6 \%)$ и тошноту $(21,7 \%)$. Оценка онкологического эффекта дальнейшего хирургического вмешательства включала уровень R0 резекции, который составил 97,8\%, и среднее количество удаленных регионарных лимфатических узлов - 18,5. Морфологический полный регресс составил $13,0 \%$. Послеоперационные осложнения отмечали у $7(15,2 \%)$ пациентов из них степень 3 (по классификации Clavien Dindo) - у 2 пациентов. Все случаи осложнений были успешно пролечены консервативно без необходимости в повторных операциях. Не было отмечено случаев летальности, связанной с лечением. Отдаленные результаты были следующими: общая 3 -летняя выживаемость $-30,1 \%$, безрецидивная 3 -летняя выживаемость - 28,5\%. Выводы. Результаты проведенного исследования свидетельствуют об эффективности и безопасности НАХТ с последующей ЛСРЖ или ЛГЕ с D2лимфодисекцией при местно-распространенном раке желудка. Послеоперационные осложнения при комбинации НАХТ с ЛСРЖ или ЛГЕ составили небольшой процент и не требовали дополнительных хирургических манипуляций.

Ключевые слова: неоадъювантная терапия; рак желудка; гастректомия.

\section{Neoadjuvant chemotherapy followed by laparoscopic D2 gastrectomy in the treatment of advanced T3-4 resectable gastric cancer.}

\section{A.V. Lukashenko, A.V. Boiko}

National Cancer Institute, Kiev

Summary. Introduction. The prognosis for patients with advanced gastric cancer remains poor, highlighting the need to improve treatment strategies. We analyzed data of patients with resectable advanced gastric cancer who received neoadjuvant chemotherapy (NAC) followed by laparoscopic distal subtotal gastrectomy (LDSG) or gastrectomy (LG) with D2 lymphadenectomy to assess the efficacy and safety of the combination of these treatments. Methods. In the study were included patients with advanced gastric adenocarcinoma (cT3-4 and/or N + M0) who received neoadjuvant chemotherapy XELOX (three preoperative and three postoperative 2-week cycles) at the National Cancer Institute from 2016-2018. The stage of disease was clarified by laparoscopic diagnostic laparoscopy before starting treatment. LDSG or LG was performed 3-4 weeks after completion of the last cycle of preoperative chemotherapy. The volume of surgical intervention was determined according to the location and type of tumor growth. Results. The 


\section{Оригінальні статті / Original Articles}

study analyzed data from 46 patients. 40 patients $(86.9 \%)$ received three courses of XELOX, while 6 patients $(13,1 \%)$ received two courses of treatment. The degree of tumor response to chemotherapy was assessed in accordance with the RECIST criteria. Complete response after NAC was observed in $7(15,2 \%)$ patients, partial response - in $29(63,0 \%)$, stable disease - in $6(13,0 \%)$, in 4 patients $(8,2 \%)$ - progression during treatment. The spectrum of NAC adverse reactions grade $3 / 4$ included: leukopenia $(21,7 \%)$, neutropenia $(32,6 \%)$, anemia $(17,4 \%)$, weight loss $(19,6 \%)$ and nausea $(21,7 \%)$. The assessment of the oncological effect of further surgical intervention included the R0 level of resection, which was $97,8 \%$, and the average number of delivered regional lymph nodes was 18,5. Morphological complete regression was $13,0 \%$. Postoperative complications were noted in $7(15,2 \%)$ patients, grade III (according to the Clavien-Dindo classification) were observed in 2 patients. All complications were successfully treated conservatively without the need for reoperation. There were no cases of treatment-related mortality. Long-term results were: 3 -year overall survival rate is $30,1 \%$, disease-free survival rate $-28,5 \%$. Conclusions. The results of this study showed the efficacy and safety of NAC followed by LDSG or LG with D2 lymphadenectomy in advanced gastric cancer. Postoperative complications rate was relatively low in the combination of NAC with LDSG or LG, and did not require additional surgical procedures.

Key words: neoadjuvant therapy; gastric cancer; gastrectomy.

Aдреса:

Бойко Артем Володимирович

03022, Київ, вул. Ломоносова, 33/43

Національний інститут раку

E-mail:artboymed@gmail.com 